\title{
IASP Beijing-kongress 2011
}

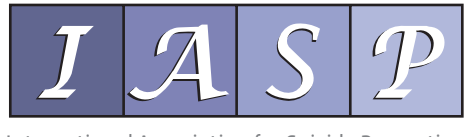

Ved Christian Kuran

Den internasjonale foreningen for selvmordsforebygging (IASP) arrangerte 13. til 17. september 2011 den 26. verdenskongressen i Beijing, Kina. Dette var andre gang IASP-kongressen ble arrangert i et asiatisk land. IASP har som formål å forebygge suicidal adferd, redusere dets effekter og skape et forum for akademikere, de som jobber innen mental helse, frivillige og pårørende. I skrivende stund består medlemsorganisasjonen av rundt 400 medlemmer fra 54 ulike land.

Verdenskongressen som holdes annethvert år, og alltid på et nytt kontinent, er en av IASPs kjerneaktiviteter. I 2009 fant den sted i Montevideo, Uruguay, i år var det litt utenfor Beijing, Kinas hovedstad. Lang reisevei var medvirkende for antall deltakere på kongressen, samtidig som reisestipender fra blant annet Care for Life Foundation i Hong Kong åpnet muligheten for at forskere og andre interesserte fra lavinntektsland kunne komme. Til sammen var det over 400 deltakere fra 45 land. Over 40 personer og organisasjoner søkte om medlemsskap i IASP i løpet av kongressen.

Tema for kongressen var "Integrating cultural perspectives in the understanding and prevention of suicide”, som ga en god spredning i programmets innhold. I tillegg til det vitenskapelige programmet brukte IASP muligheten til å knytte nettverk innad og presentere resultater og aktiviteter fra individuelle medlemmer og medlemsorganisasjonene.

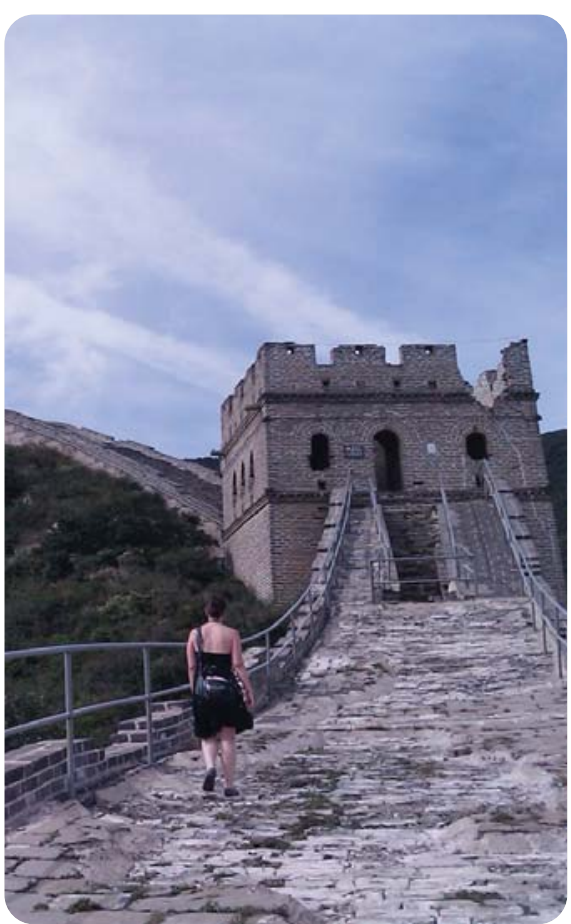

Det ble i forbindelse med kongressen organisert ture bl.a. til den kinesiske mur. (Foto: Christian Kuran)
I løpet av kongressen ble det holdt møter i styret, generalforsamlingen og andre instanser. I m $\phi$ tet for nasjonale representanter i IASP ble det blant annet bestemt at kongressen i 2015 skal finne sted i Montreal.

IASP organiserer interesserte i suicidologirelaterte temaer eller prosjekter i Task Forces; grupper opprettet med formål om å gjennomføre et konkret tidsbegrenset prosjekt eller unders $\varnothing$ kelse, og Special Interest Groups, som har fokus på et spesielt tema over lengre tid. For eksempel ser medlemmene i Special Interest Group Suicide and the Workplace spesielt på spørsmål knyttet til suicidologi og arbeidsliv. På møtene under konferansen ble det gruppene hadde jobbet med siden siste kongress presentert, og aktuelle fremtidige prosjekter eller temaer. I løpet av kongressen ble det opprettet to nye Special interest groups - én om kulturelle- og menneskerettighetsperspektiver på selvmord, og én om selvmordsklynger. Mer informasjon om de ulike gruppene og hvordan det er mulig å bidra på et internasjonalt plan finner du på IASPs websider (www.iasp.info).

For deltakere som også ønsket å se mer av Kina var det mulig å dra til Beijing på eget initiativ, bli med på en av de organiserte turene til den kinesiske muren eller delta på "Beijing night tour" for å se Beijings yrende natteliv. På nest siste dag av kongressen ble det holdt gallamiddag med kulturelle innslag, blant annet Kung Fuakrobatikk og maskespill.

IASP fordeler også ulike priser annet hvert år. På verdenskongressen i Beijing ble følgende IASP-priser delt ut:

The Stengel Research Award 2011 til Paul Yip fra Hong Kong

2011 Ringel Service Award til Jose M Bertolote fra Geneve 2011 De Leo Fund Award til Eugene Kinyanda fra Uganda Mer om prisene kan du lese på http://www.iasp.info/awards.php

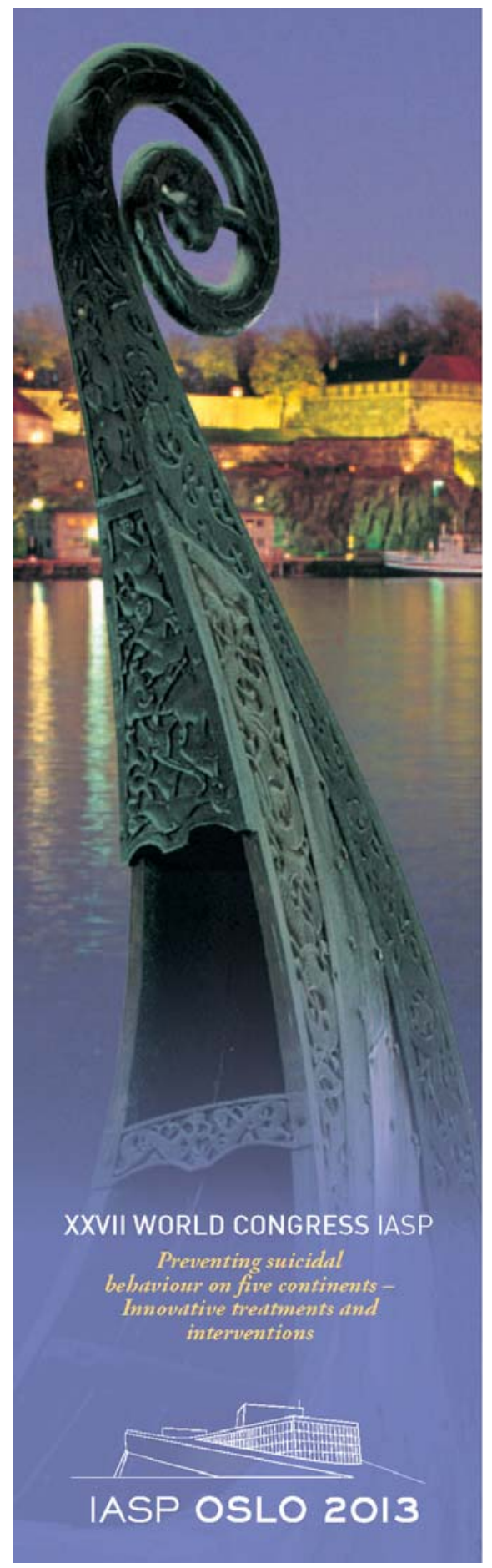

Den 27. IASP World Congress skal arrangeres i Oslo i 2013 
IASPs verdenskongress i Beijing i år stilte med et rikt og variert innhold. Det ble holdt tre workshops i forkant av kongressen. Hver dag var det to plenarer med tre til fire forelesninger fra anerkjente seniorforskere med flere tiårs erfaring bak seg. I tillegg var det to parallellsesjoner med fire presentasjoner i hver, og to postersesjoner hver dag. Det var nye postere hver dag. To av workshopene var rent klinisk orientert, mens en av dem handlet om hvordan kunst kan brukes til å avdekke undertrykket eller latent innsikt i egen erfaring med selvmordsatferd. Flere plenarer var en blanding av epidemiologisk og klinisk materiale, brukt til å belyse selvmordsforebygging på forskjellige måter og fra flere deler av verden, som Kina, USA og Danmark. Alder og kjønn var to av de mest bestandige faktorer som demonstrerte kompleksiteten i suicidologisk epidemiologi. I de kliniske plenarene ble både mental helse og psykososiale faktorer gjentatte ganger referert til. Ingen av plenarene var rent biologisk eller kulturelt orientert.

Plenarenes hovedfokus var hvordan bruke eksisterende kunnskap i selvmordsforebygging, intervensjon og postvensjon. Plenar ved psykolog og førsteamanuensis ved University of North Texas, Cindy
Claassen, som omhandlet en sammenlikning av de planlagte endringer i DSM V og ICD-11 vedrørende suicidal atferd, hadde implikasjoner for både epidemiologi og klinisk forskning, ikke bare klinisk praksis.

Parallellsesjonene og posterne, på den annen side, hadde både biologiske og kulterelle perspektiver. Flere intervensjoner, både fra kliniske og ikke-kliniske grupper, ble også presentert. Professor i psykologi og direkt $\varnothing$ r ved Senteret for selvmordsforskning og intervensjon ved universitetet i Quebec, Brian Mishara, hadde et muntlig innlegg om intervensjon med politiansatte i Canada. Denne presentasjonen, som også viste bilder av politifolk i opplæringssesjoner på temaet selvmordsatferd, er lagret i hukommelsen som et godt eksempel på kraften av fellesskap og en organisasjon som bryr seg om sin viktigste ressurs: de ansatte. En annen muntlig presentasjon, ved psykolog og forsker ved Senter for samisk helseforskning, Karasjok, institutt for samfunnsmedisin, Universitetet i Troms $\varnothing$, Anne Silviken og hennes kolleger, gjorde også inntrykk i betoningen av etniske faktorer ved utformingen av en intervensjon. De minnet meg om tilsvarende intervensjoner i Australia som ble presentert ved IASP-kongressen i
Uruguay i 2009 og ved IASP-konferansen i Brisbane i 2010.

NSSF hadde også flere presentasjoner i Beijing. Dessuten var det et symposium som ble ledet av professor Lars Mehlum og forsker Erlend Mork. Alle framlegg ble godt mottatt og genererte den type diskusjon som fører til utveksling av ideer og kontaktinformasjon, noe som fremmer faget. Blant dem som kontaktet meg var to byråkrater fra Utdanningsdepartementet i Singapore. De ønsket å vite mer om hvordan suicidal adferd blant elever på videregående skole kan forhindres. At IASP-kongressene betraktes som viktige, ikke bare fra forskerhold og klinikere, men også byråkrater, er en indikator på hvor inkluderende disse kongressene er, uten kompromiss på kvalitet. Det er denne relevansen for samfunnet som helhet som gjør verdenskongresser som denne uvurderlig. Den 26. verdenskongressen i Beijing ved IASP var mer enn en idéutveksling og kunnskapspresentasjon - den var frukten av tiår med hardt arbeid av IASP. medlemmer - for å bygge en plattform der alle som er dypt engasjert i selvmordsforebygging kan møtes, uavhengig av grenser. 24.-28-. september 2013 arrangeres IASPs 27. verdenskongress i Oslo.

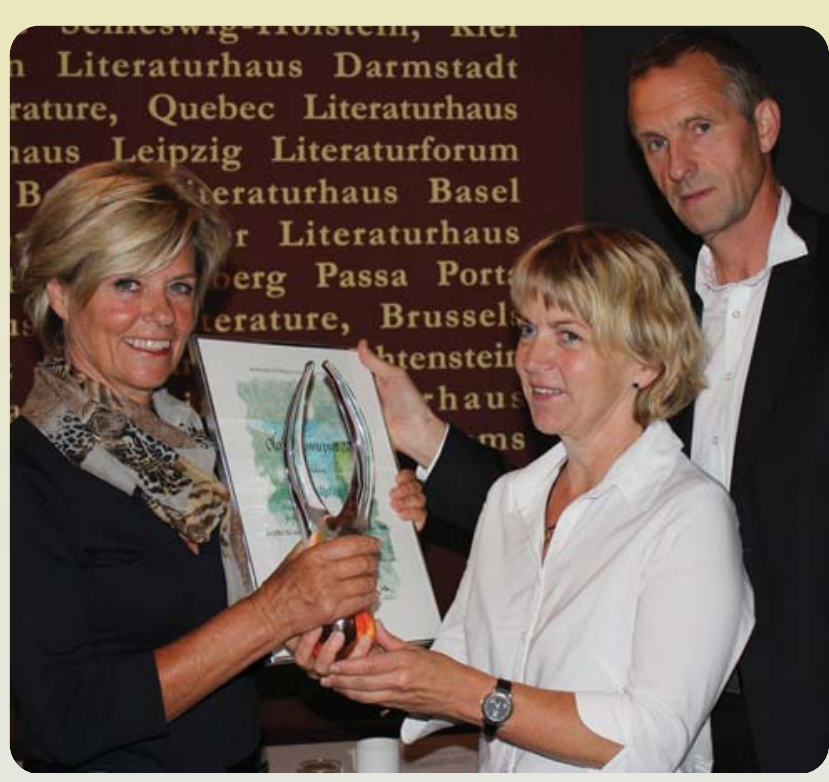

Mette Ystgaard t. v. , overrekkes prisen av stiftere av Olafs Minnefond, Mette Marie Tangen og Jon Schultz.

\section{Pårørende hedrer forsker}

Fredag 2. september 2011 ble Olafs Minnepris delt ut for første gang. Prisen ble utdelt av Olafs Minnefond for forebygging av selvmord blant unge, nylig etablert av Mette Marie Tangen og Jon Schultz, foreldre til Olaf som tok sitt eget liv i sommer, 19 år gammel. Olafs Minnefond er opprettet av Olafs foreldre og søsken for at Olafs d $\varnothing \mathrm{d}$ ikke skal være forgjeves.

Prisen for 2011 gikk til forsker Mette Ystgaard ved Regionssenter for barn og unges psykiske helse $\varnothing_{\text {st og }}$ Sør. Hun har utmerket seg gjennom fremragende forskningsinnsats knyttet til selvmordsproblematikk blant unge i Norge. Et fagutvalg bestående av professor dr. med. Lars Mehlum (leder), professor em. Berit Grøholt og forsker PhD. Anne Silviken har foretatt innstillingsarbeidet. Prisen ble delt ut i forbindelse med den nasjonale markeringen av Verdensdagen for selvmordsforebygging.

I 2012 tar fondet sikte på å dele ut tre priser. En pris innenfor forskning, en pris innenfor opplysningsarbeid og en pris innenfor journalistikk. http://www.olafsminne.org/

Tekst: Ina Bekkevold / foto: Christian Kuran 